\title{
Prevalence of Catha edulis (Khat) Chewing and Its Associated Factors among Ataye Secondary School Students in Northern Shoa, Ethiopia
}

\author{
Awoke Lakew', Behailu Tariku², Nigussie Deyessa ${ }^{3}$, Yared Reta ${ }^{3}$ \\ ${ }^{1}$ Ataye District Hospital, North Shoa, Ataye, Ethiopia \\ ${ }^{2}$ Health Information Technology Departments, Debre Birhan Health Science College, Debre Birhan, Ethiopia \\ ${ }^{3}$ Debre Birhan University, Debre Birhan, Ethiopia \\ Email: lakewawoke@gmail.com, minastariku@gmail.com, nedyaysun@yahoo.com, yared2002@yahoo.com
}

Received 10 August 2014; revised 4 September 2014; accepted 16 September 2014

Copyright (C) 2014 by authors and Scientific Research Publishing Inc.

This work is licensed under the Creative Commons Attribution International License (CC BY).

http://creativecommons.org/licenses/by/4.0/

\section{(c) (i) Open Access}

\section{Abstract}

The life time and current prevalence of khat chewing are $15.36 \%(95 \% \mathrm{CI} ; 11.7,19.8)$ and $13.25 \%$ (95\% CI; 11.0, 18.1) respectively. Multivariable logistic regression model revealed that male students [Adjusted OR $=2.15(95 \% \mathrm{CI} ; 1.02,4.56)]$, presence of chewer friends [Adjusted $\mathrm{OR}=3.14$ (95\% CI; 1.53, 6.41)], having chewer family [Adjusted OR $=2.68(95 \% \mathrm{CI} ; 1.13,6.37)]$ and place of residency [Adjusted $\mathrm{OR}=\mathbf{1 . 8 9}(95 \% \mathrm{CI}$; 1.0, 3.79)] were associated risk factors for khat chewing. Khat chewing is prevalent among students who are male, urban residents and students who have chewer friends and family. Therefore, to reduce the prevalence, social, economic and health effect of khat chewing, Minister of Education in collaboration with Ministry of Health has to work to incorporate life skill training in high school students' curricula.

\section{Keywords}

Ataye, Cathinone, Khat, Northern Shoa and Prevalence

\section{Introduction}

Catha edulis (khat) plant is an evergreen tree of family Celastraceae. The leaves of khat contain alkaloids structurally related to amphetamine. Khat is extensively cultivated in the highlands of Ethiopia (Reda et al., 2012) and surrounding countries like Kenya, Yemen and other African countries (Deressa \& Azazh, 2011; Lemessa, 2001).

How to cite this paper: Lakew, A., Tariku, B., Deyessa, N. and Reta, Y. (2014). Prevalence of Catha edulis (Khat) Chewing and Its Associated Factors among Ataye Secondary School Students in Northern Shoa, Ethiopia. Advances in Applied Sociology, 4, 225-233. http://dx.doi.org/10.4236/aasoci.2014.410027 
The bud of khat contains the chemical called cathinone and cathine. Cathinone is more lipids soluble than cathine and it can easily cross the brain blood barrier (BBB) and enter in the central nervous system that is responsible for adverse effect on the body. Similarly, it has amphetamine like structure and causes similar effect on the body (Dawit \& Asfaw, 2005). Khat is chewed daily by a high proportion of adult population for its Central Nervous System stimulant effect (Hussein, 2009). Furthermore, it is widely masticated among youth Ethiopians, especially high school, college and university students (Damena et al., 2011). Its effects on the chewers include increased levels of energy, increased self-esteem, euphoria, increased libido, excitement, and increased proclivity for social interaction (Deressa \& Azazh, 2011; Oshodi et al., 2010). Even though khat chewing has addictive and negative physical, economical and social connotation effects, it has positive economic, social and medicinal values (Lemessa, 2001). In Ethiopia, khat is commonly used for stimulation and social recreation. Students are frequent users of khat before examination to have concentration, thereby to improve mental performance (EPHA, 2012; Kennedy et al., 1983; Hussein, 2009).

Many studies in Africa and outside reveal that the life time prevalence and current prevalence of khat chewing in high school, college and university students vary from place to place. These could be explained as in Kenyan high school the prevalence was 3.2\% (Ndetei et al., 2010), 24.2\% (95\% CI; 22.2\% - 26.2\%) in Eastern Ethiopia high schools (Reda, 2012), 21.4\% in Jazan high school (Hussien, 2009), 23.1\% in higher education of Jazan region of Saudi Arabia (Reshad, 2013) and 10.9\% in Dire Dawa high school (Ethiopia) (Negussie et al., 2014). Moreover, the prevalence increases as we go from high school to college and university students. A research done in Bahir Dar College showed that the prevalence of khat chewing was 19.6\% (Mulugeta, 2013). Research conducted by (Kebede, 2002) in North West Ethiopia colleges showed that life time prevalence was $26.7 \%$ and current prevalence was $17.5 \%$. On the hand, the prevalence of khat chewing in different universities of Ethiopia was indicated in researches conducted by different investigators, for instance, $28.7 \%$ by (Gebresilassie et al., 2013), 7.8\% by (Aklog et al., 2013), 14.1\% by (Deressa \& Azazh, 2011) and 30.3\% by (Derese \& Seme, 2014). The above mentioned investigators findings depicted that there were many factors associated with khat chewing among students. Of which, most studies (Deressa \& Azazh, 2011; Oshodi et al., 2010; Kebede et al., 2005; EPHA, 2006) showed that being male, having peers who chewed khat, having family members who chewed khat, residence place, religion and seniority in the case of college/university students were statistically significant.

Khat chewing nowadays has become an epidemic over East Africa especially in Ethiopia, Somali and southern Arab from the old to young, male and female, urban and rural settings (Getahun et al., 2010). Moreover, many adolescents have low knowledge towards adverse effects of khat chewing as indicated in literature (Oshodi et al., 2010). Though khat chewing has become a common practice among high school, college and university students in Ethiopia, few studies have assessed the prevalence and associated factors. Although there was a murmur of khat chewing among high school students in Ataye high and preparatory school, the magnitude and associated factors were not yet investigated. Therefore, the intent of this study was to establish the prevalence of khat chewing and associated factors among Ataye high school students and preparatory school students.

\section{Methods and Materials}

\subsection{Study Area and Design}

Cross sectional study design was applied among Ataye high school students in May 2014. Ataye district is one of the 22 districts found in Northern Shoa around $280 \mathrm{KM}$ away from the capital of Ethiopia, comprising a total population of 125,914 (ADHO, 2014). In the district, there are one preparatory and one high school. These schools enrolled a total of 2000 students $($ Male $=1025$ and Female $=975)$ from Grade 9 - 12. Students who were attending preparatory and high school from Grade 9 to 12 were included in the study while students who were very sick were excluded from the study.

Single proportion (adjusted formula) was used, taking prevalence 24.2\% (Reda et al., 2012), 10\% of nonrespondent rate and due to multistage nature of sampling technique 1.5 design effect was used. The marginal error was taken as 5\% with $95 \%$ confidence level. Multistage sampling technique was used to select a representative sample of 378 students.

Out of 38 sections (Grade 9 composed of 19 sections, Grade 10 composed of 10 sections, Grade 11 composed of 5 sections and Grade 12 composed of 4 sections), 8 sections were selected as a primary sampling units (PSU). Accordingly, from Grade 9 four sections, from Grade 10 two sections, from Grade 11 one section and from Grade 12 one section were selected by using lottery methods. To select study units from each sections systemat- 
ic random sampling was used.

\subsection{Study Variable Measurements}

Two categories of variables were used in this study. The dependent variable was khat chewing status of the students. Ever chewed was defined as a student who had ever tried chewed khat in the past, even once. Current chewer was defined as a student who had chewed khat on one or more days in the preceding month ( 30 days) of the survey. The former is said to be life time prevalence, whereas the latter one is current prevalence rate. Independent variables were; age, sex, grade, residential area, having family/peer/relative chewers, religion and others.

\subsection{Data Collection Procedure}

The English version of self administered structured questionnaire was developed by the investigators adapting from literatures. Then it was translated to Amharic language which is the official working language of the study area (Ethiopia). The consistency of the translation from English to Amharic was checked by English teachers in Ataye preparatory and high schools. Ahead of data collection 7 peoples were recruited from Ataye District Hospital for data collection. Of whom 3 were BSc nurses and 3 were BSc supportive staffs and the one was supportive supervisor. To keep the quality of data, data collectors and supervisor were given training for one day regarding necessary explanations about the research and how to answer for any questions that arise from the respondents. Pre-test was done on 16 students who were not included in the study.

\subsection{Data Processing and Analysis}

Data were cleaned, coded and entered into Epi Info software version 3.5.1. Then these data were exported to SPSS version 16.0 for analysis. Descriptive statistics such as frequency, percentage, mean, standard deviation were calculated for some variables. Data presentation was done using frequency distribution tables. Generalized linear model (GLM) called logistic regression was used to identify factors affecting khat chewing behavior of students. Coefficients of binary logistic regression were estimated by Wald statistics. Odds ratio [expo ( $\beta$ )] of logistic regression coefficients indicate the chance of increasing $(\mathrm{OR}>1)$ or decreasing $(\mathrm{OR}<1)$ of khat chewing when treated with different explanatory variables. The cutoff point for bivariable logistic regression was declared at $p<0.2$ to include variables in multivariate logistic regression. Statistical significance is confirmed at $p$ value less than 0.05 .

\section{Result}

\subsection{Socio-Demographic Characteristics of the Respondents}

Three hundred and seventy eight students were planned to be recruited in this study. But three hundred and thirty two students returned questionnaires giving a response rate of $88 \%$. The percentage of male students was $53.6 \%$. The majority $(88.25 \%)$ of the respondents was found in age group between $12-18$ years. while the mean age (Mean \pm SD) was $17.21 \pm 1.42$ (Table 1$)$.

\subsection{Socio-Demographic Characteristics of Current Khat Chewers}

The life time and current prevalence rate of khat chewing were $15.36 \%$ at $95 \% \mathrm{CI}(11.7,19.8)$ and $13.25 \%$ at $95 \%$ CI $(11.02,18.01)$ respectively. Out of the 51 chewers more than half $24(54.54 \%)$ of them started khat chewing at Grade 8 . On the other hand out of forty-four who currently chew khat $38(86.36 \%)$ were in the age group between 12 and 18, and 75\% were male students, $68.18 \%$ were orthodox Christian, followed by Muslim $27.27 \%$. As regards the residential place of the chewers $29(65.9 \%)$ of chewers reside in urban (Table 1$)$.

Out of the current chewers, nearly half of them 21(47.7\%) chew khat once in a month. More than half 23 $(52.9 \%)$ get khat from nearby shop. Others get form coffee house and street market. The main reasons were recreational $19(43.2 \%)$ and $15(34.1 \%)$ for studying purpose. Nearly one third of the students $16(36.4 \%)$ believed that khat chewing has no effect on educational result. Moreover, the same amount of students believes that khat chewing decrease educational performance. About 18 (40.1\%) of the chewer get money from their family and more than half 29 (65.9\%) used nothing during and after khat chewing and only 8 (18.2\%) of chewers used alcohol after chewing. Most of the parents 20 (45.5\%) of the students were unresponsive towards the khat chewing 
Table 1. Socio-demographic characteristics of current khat chewers and non-chewer students of Ataye high and preparatory school in May $2014(\mathrm{~N}=332)$.

\begin{tabular}{|c|c|c|c|c|c|}
\hline Variables & $\mathbf{N}=\mathbf{3 3 2}$ & \multicolumn{2}{|c|}{ Frequency } & Percent & $95 \% \mathrm{CI}$ \\
\hline Life Time Chewers & \multicolumn{3}{|c|}{51} & 15.40 & $11.7-19.8$ \\
\hline \multirow[t]{3}{*}{ Current Chewers } & & 44 & & 13.25 & $11.0-18.1$ \\
\hline & & \multicolumn{2}{|c|}{ Chewers } & \multicolumn{2}{|c|}{ Non-Chewers } \\
\hline & & Frequency & Percent & Frequency & Percent \\
\hline \multicolumn{6}{|l|}{ Age } \\
\hline Between 12 and 18 & $293(88.25 \%)$ & 38 & 11.44 & 255 & 76.80 \\
\hline Between 19 and 28 & $39(11.75 \%)$ & 6 & 1.81 & 33 & 9.94 \\
\hline \multicolumn{6}{|l|}{ Sex } \\
\hline Male & $178(53.61 \%)$ & 33 & 9.94 & 145 & 43.67 \\
\hline Female & $154(46.39 \%)$ & 11 & 3.31 & 143 & 43.07 \\
\hline \multicolumn{6}{|l|}{ Level of Grade } \\
\hline Grade 9 & $166(34.94 \%)$ & 13 & 3.91 & 103 & 31.02 \\
\hline Grade 10 & $72(21.68 \%)$ & 12 & 3.61 & 60 & 18.07 \\
\hline Grade 11 & $79(23.79 \%)$ & 6 & 1.81 & 73 & 21.98 \\
\hline Grade 12 & $65(19.58 \%)$ & 13 & 3.91 & 52 & 15.66 \\
\hline \multicolumn{6}{|l|}{ Religion } \\
\hline Orthodox & $291(87.65 \%)$ & 30 & 9.03 & 261 & 78.61 \\
\hline Muslim & $31(9.34 \%)$ & 12 & 3.61 & 19 & 5.72 \\
\hline Protestant & $10(3.01 \%)$ & 2 & 0.60 & 8 & 2.41 \\
\hline \multicolumn{6}{|l|}{ Residence } \\
\hline Urban & $165(49.69 \%)$ & 29 & 8.73 & 136 & 40.96 \\
\hline Rural & $167(50.31 \%)$ & 15 & 4.52 & 152 & 45.78 \\
\hline \multicolumn{6}{|l|}{ With Khat Chewers } \\
\hline Alone & $103(31.02 \%)$ & 15 & 4.52 & 88 & 26.5 \\
\hline Family & $199(59.94 \%)$ & 22 & 6.63 & 177 & 53.31 \\
\hline Friend & $30(9.04 \%)$ & 7 & 2.11 & 23 & 6.93 \\
\hline
\end{tabular}

practice of their children. But sixteen parents disagree for their children khat chewing habit. From the current khat chewers $36(81.8 \%)$ chew khat with their friends. Considering the side effects of khat, more than half 27 $(61.36 \%)$ of current chewers promised to stop khat chewing practice in the future (Table 2 ).

\subsection{Bivariate and Multivariate Analysis}

Multivariate analysis was employed to assess the net effect of socio-demographic, explanatory variables on khat chewing. The result of binary logistic regression model revealed that respondents sex, place of residence and having chewer friends significantly associated with khat chewing. Sex was found to be one of the associated factors for khat chewing among Ataye preparatory and high school students. Male students were 2 times more likely to chew khat than female students [Adjusted $\mathrm{OR}=2.15,95 \% \mathrm{CI}=(1.02,4.56)$ ]. Student's residential place was found significant with khat chewing. Those students who come from urban area were almost 2 times more likely to chew khat than students from rural areas [Adjusted OR $=1.89,95 \% \mathrm{CI}=(0.95,3.79)$ ]. Having chewer friend was one of the factors which associated with khat chewing. Those students who have chewer friends were chewed khat about 3 times more likely than their counterpart [Adjusted OR $=3.14,95 \% \mathrm{CI}=(1.53$, $6.41)$ ]. Besides, students who have chewer family were chewed khat 2.68 times more than those students who did not have family who chew khat [Adjusted $\mathrm{OR}=2.68,95 \% \mathrm{CI}=(1.13,6.37)$ ]. Contrary, grade level of students was statistically significant in the binary (crude) analysis but not when adjusted for other variables in the model. In this study religion, category of age, having khat chewer relatives and living either with family or alone have no association with khat chewing (Table 3 ).

\section{Discussion}

This study tried to investigate the prevalence and associated risk factors of high school and preparatory school students in Ataye town. The scope was limited to Ataye high and preparatory school, so that this may be the potential limitation of the study. Moreover, the findings of this study may not be necessarily applicable to out-ofschool adolescents where the use of khat might be higher. Even if the respondent rate was satisfactory (88\%), based on these data findings the following explanation was made. 
Table 2. Experience of current khat chewers among students of Ataye high and preparatory school in May $2014(\mathrm{~N}=332)$.

\begin{tabular}{|c|c|c|}
\hline Variables & Frequency & Percent (\%) \\
\hline \multicolumn{3}{|l|}{ How many times did u chew khat? } \\
\hline Daily & 4 & 9.1 \\
\hline Twice a week & 13 & 29.5 \\
\hline Once a week & 6 & 13.6 \\
\hline Once a month & 21 & 47.7 \\
\hline \multicolumn{3}{|l|}{ Where do you get khat for chewing? } \\
\hline From nearby shop & 23 & 52.3 \\
\hline From street peddlers & 14 & 31.8 \\
\hline From coffee/restaurant house & 7 & 15.9 \\
\hline \multicolumn{3}{|l|}{ What is the common reason for khat chewing? } \\
\hline Recreational & 19 & 43.2 \\
\hline Studying & 15 & 34.1 \\
\hline Praying & 2 & 4.5 \\
\hline Stress relieve & 8 & 18.2 \\
\hline \multicolumn{3}{|c|}{ What was your family response for your khat chewing practice? } \\
\hline Agree & 8 & 18.2 \\
\hline Disagree & 16 & 36.4 \\
\hline Indifferent & 20 & 45.5 \\
\hline \multicolumn{3}{|c|}{ What do you think the influence of khat chewing on education? } \\
\hline Increase educational performance & 12 & 27.3 \\
\hline Decrease educational performance & 16 & 36.4 \\
\hline No effect on educational performance & 16 & 36.4 \\
\hline \multicolumn{3}{|l|}{ Common source of money to buy khat? } \\
\hline Family & 18 & 40.9 \\
\hline Friends & 9 & 20.5 \\
\hline Relatives & 4 & 9.1 \\
\hline My income & 13 & 29.5 \\
\hline \multicolumn{3}{|l|}{ Commonly with whom did you chew khat? } \\
\hline Alone & 4 & 9.1 \\
\hline Family & 4 & 9.1 \\
\hline Friends & 36 & 81.8 \\
\hline \multicolumn{3}{|l|}{ Where did you commonly chew khat? } \\
\hline At school & 3 & 6.8 \\
\hline At home & 9 & 20.5 \\
\hline At coffee house & 15 & 34.1 \\
\hline In a separate place & 17 & 38.6 \\
\hline \multicolumn{3}{|l|}{ What did you used after chewing khat? } \\
\hline Alcohol & 8 & 18.2 \\
\hline Cigarette & 5 & 11.4 \\
\hline Shisha (Hookah) & 2 & 4.5 \\
\hline Nothing & 29 & 65.9 \\
\hline
\end{tabular}

This study revealed that the life time and current prevalence rate of khat chewing among students were $15.36 \%$ and 13.25 respectively. The findings of this study give the impression to be lower than studies conducted in other parts of the country. A study from Eastern Ethiopia (Nigussie et al., 2014) revealed that the prevalence of khat chewing among high school students to be $18.4 \%$. Similarly a survey conducted among high school students in Eastern Ethiopia (Reda et al., 2012) showed that the prevalence was 24.2\%. (Kebede, 2002) conducted a research in four colleges found in North West Ethiopia publicized that the life time and current prevalence of khat chewing was $26.7 \%$ and $17.5 \%$ respectively. Likewise, study conducted by (Mulugeta, 2013) among college students in Bahir Dar town indicated that the overall prevalence of chewing was $19.6 \%$. Khat chewing was found in different universities of Ethiopia in higher prevalence of the following areas; $28.7 \%$ in Axum University (Gebreselassie et al., 2013) and 30.3\% in Haramaya University (Derese \& Seme, 2014). Generally, the life time pooled and current pooled prevalence of khat in Ethiopia was $20 \%$ and $28.3 \%$ respectively (Bitew \& Tefera, 2014). In a similar fashion, study conducted in Jazan region of Soudi Arabia College and high school (Hussien, 2009), the prevalence in high school was 21.5\%. Besides, (Alsanosy et al., 2013) estimated that the prevalence was $20.5 \%$ in Jazan. Furthermore, Rashad and his colleagues (2013) reported that the prevalence of khat chewing among higher education in Jazan region of soudi Arabia was $23.1 \%$. Contrary to our study, study conducted in Kenya high school (Ndetie et al., 2010) showed the prevalence of khat chewing was minimal 
Table 3. Bivariate and multivariate regression model estimates of risk factors for khat chewing among Ataye high and preparatory school students in North Shoa, Ethiopia 2014.

\begin{tabular}{|c|c|c|c|c|}
\hline \multirow{2}{*}{$\begin{array}{c}\text { Explanatory Variables } \\
\text { Age Category }\end{array}$} & \multicolumn{2}{|c|}{ Khat Chewing Status } & \multirow{2}{*}{ COR $(95 \%$ CI) } & \multirow{2}{*}{ AOR $(95 \%$ CI $)$} \\
\hline & YES [No. (\%)] & NO [No. (\%)] & & \\
\hline $\begin{array}{l}12-18 \\
19-28\end{array}$ & $\begin{array}{c}38(11.45 \%) \\
6(5.25 \%)\end{array}$ & $\begin{array}{c}255(78.38 \%) \\
33(9.9 \%)\end{array}$ & $\begin{array}{c}1.22(0.48,3.11) \\
1\end{array}$ & \\
\hline \multicolumn{5}{|l|}{ Sex } \\
\hline Male & $33(9.9 \%)$ & $145(43.67 \%)$ & $2.96(1.44,6.08)$ & $2.15(1.02,4.56)$ \\
\hline Female & $11(3.3 \%)$ & $143(43.1 \%)$ & 1 & 1 \\
\hline \multicolumn{5}{|l|}{ Place of Residence } \\
\hline Urban & $29(8.73 \%)$ & $136(40.96 \%)$ & $2.16(1.11,4.20)$ & $1.89(0.95,3.79)$ \\
\hline Rural & $15(4.52 \%)$ & $152(45.78 \%)$ & 1 & 1 \\
\hline \multicolumn{5}{|l|}{ Grade Level } \\
\hline 9th & $13(3.92 \%)$ & $103(31.02 \%)$ & $1.98(0.86,4.58)$ & \\
\hline 10th & $12(3.61 \%)$ & $60(18.07 \%)$ & $1.25(0.53,2.97)$ & \\
\hline 11 th & $6(1.80 \%)$ & $73(21.89 \%)$ & $3.04(1.08,8.52)$ & \\
\hline 12 th & $13(3.92 \%)$ & $52(15.66 \%)$ & 1 & \\
\hline \multicolumn{5}{|l|}{ Family Chew Khat } \\
\hline Yes & $10(3.01 \%)$ & $25(7.53 \%)$ & $3.09(1.37,6.99)$ & $2.68(1.13,6.37)$ \\
\hline No & $34(10.24 \%)$ & $263(79.22 \%)$ & 1 & 1 \\
\hline \multicolumn{5}{|l|}{ Peer Chew Khat } \\
\hline Yes & $31(9.34 \%)$ & $118(35.54 \%)$ & $3.44(1.73,6.84)$ & $3.14(1.53,6.41)$ \\
\hline No & $13(3.91 \%)$ & $170(51.20 \%)$ & 1 & 1 \\
\hline \multicolumn{5}{|l|}{ Relatives Chew Khat } \\
\hline Yes & $7(2.11 \%)$ & $54(16.26 \%)$ & $1.22(0.52,2.88)$ & \\
\hline No & $37(11.14)$ & $234(70.48 \%)$ & 1 & \\
\hline \multicolumn{5}{|l|}{ Students Live with } \\
\hline Alone & $15(4.52 \%)$ & $88(26.50 \%)$ & $1.78(0.65,4.89)$ & \\
\hline With family & $22(6.63 \%)$ & $177(53.31 \%)$ & $2.45(0.94,6.36)$ & \\
\hline With peers & $7(2.11 \%)$ & $23(6.93 \%)$ & 1 & \\
\hline
\end{tabular}

$3.2 \%$ as compared to our finding. These differences could be as a result of cultural variations among study population, difference in the characteristics of sampled population, status of understanding about the effects of $\mathrm{Ca}$ tha edulis, availability of khat and some geographical difference among study areas could be mentioned.

To appreciate the effect of time on behavioral change, we compared our findings with study from southwestern Ethiopia (Adugna et al., 1994) found that the prevalence of Khat chewing among upper secondary school students was $64.9 \%$. A survey conducted in a rural community in southern Ethiopia establishes a prevalence of $50 \%$ (Alem et al., 1999). In addition, study conducted in Somalia reported that approximately $36.4 \%$ of the respondents had chewed Khat in the week preceding the interview (Odenwald et al., 2007). The difference may be stimulated by studies were conducted many years back, rules and regulation enforcement differences. Another study done in Addis Ababa among undergraduate medical students showed life time prevalence of $7 \%$ and current prevalence of 4\% (Deressa \& Azazh, 2011) and study done in Ayder medical school in Mekelle revealed that the life time prevalence $11.8 \%$ and current prevalence was 3.8\% (Awoke et al., 2011). But, our finding life time prevalence $15.36 \%$ and current prevalence $13.25 \%$ which is higher than these two studies. The difference may be the chewers in former studies were at above adolescent age range. The age range in Addis Ababa undergraduate medical school was $20-24(62 \%)$ and in Mekelle health science collage the age range was $21-25$ (56\%) (Deressa \& Azazh, 2011; Awoke et al., 2011) compared to our finding, only 20.5\% of students were above 20 years of age. This may show that early and middle adolescent students highly influenced by their environment and has the ambition of doing new things than late adolescent students (Abebe et al., 2005). Furthermore, those researches were done on students who were attending health related course at medical school where khat chewing is not a common practice. Besides, students in our study live with their families or friends where chewing khat is considered as normal. But, Students in Ayder Health Science College lives inside the campus where chewing khat is lawfully forbidden and punishable.

One of the determinant factors that affect the chewing practice of students was gender. In our study male stu- 
dents currently chewed khat more than female students (Table 3). Similar differences were reported in a surveys carried out in different parts of Ethiopia and other world (Aklog et al., 2013; Negussie et al., 2014; Derese \& Seme, 2014; Tilahun \& Ayele, 2014; Mulugeta, 2013; Kebede, 2001; Reda et al., 2012; Gebreslassie, 2013; Abrha, 2013; Otieno \& Ofulla, 2009; Alsanosy \& Mutwakel, 2013; Hussien, 2009). This significant difference may be due to the cultural acceptance of male practicing unusual things including khat chewing, alcohol and other substances than females in Ethiopia and it is not an exceptional in our study area.

Other significant factors identified in this study were (Table 3) having friends chewing khat having family using khat and place of residence. These predictors were statistically significant and determine khat chewing practice among Ataye high and preparatory students. Basically, this finding agrees with other studies done by different investigators (Gebreslassie et al., 2013; Abrha, 2013; Otieno \& Ofulla, 2009; Alsanosy \& Mutwakel, 2013; Mulugeta, 2013; Kebede, 2001; Negussie et al., 2014; Aklog et al., 2013; Hussien, 2009). This is because: in the first place, youths directly persuade their friends to conform to their behavior; therefore khat chewers encourage their inexperienced peers to chew khat (Al-Mugahed, 2008); in the second place, since families were significant others (model/figures) of their sons, students with parental model (parents used khat) were more prone to khat chewing than their counter parts; thirdly, higher proportion of the students in this study were come from rural area that has no previous history of khat chewing as they lived with their family. In addition to rural areas khat chewing is not a common habit, students from the rural area are under the control of their family.

\section{Conclusion and Recommendation}

Mastication of khat among high and preparatory school students is prevalent and unacceptable in magnitude. Major factors that affect khat chewing were being male, peer influence, similar habit among family members and residential place. Therefore, to reduce the prevalence, social, economic and health effect of khat chewing, Minister of Education in collaboration with Ministry of Health has to work to incorporate life skill training in high school students' curricula. Moreover, open discussion system should be established to create an understanding on the ill effects of khat thereby to bring behavioral change. Not only that, schools also need to establish and strengthen teaching and monitoring system of their students through mass media (Local FM Radio) with special focus on khat control mechanism in collaboration with Ministry of Health, local administration and merchants who buy and sell khat. Last but not least, legal rule and regulations are recommended towards the cultivation, use and sell of khat.

\section{Acknowledgements}

We would like to acknowledge the invaluable support rendered to us by the officials and the staff of Debre Birhan University, Debre Birhan Health Science College, Ataye District Hospital and Ataye High and Preparatory school. Finally, our appreciation goes to Mr. Abel Fekadu for his valuable suggestion and comments.

\section{References}

Abebe, D., Debella, A., Dejene, A., Degefa, A., Abebe, A., Urga, K., \& Ketema, L. (2005). Khat Chewing Habit a Possible Risk Behaviour for HIV Infection: A Case-Control Study. Ethiopian Journal of Health Development, 19, $174-181$. http://www.ajol.info/index.php/ejhd/article/view/9989

Adugna, F., Jira, C., \& Molla, T. (1994). Khat Chewing among Agaro Secondary School Students, Agaro, South Western Ethiopia. Ethiopian Medical Journal, 32, 161-166.

Aklog, T., Tiruneh, G., \& Tsegay, G. (2013). Assessment of Substance Abuse and Associated Factors among Students of Debre Markos Poly Technique College in Debre Markos Town, East Gojjam Zone, Amhara Regional State, Ethiopia, 2013. Global Journal of Medical Research Pharma, Drug Discovery, Toxicology and Medicine, 13, 1.

Alem, A., Kebede, D., \& Kullgren, G. (1999). The Prevalence and Socio-Demographic Correlates of Khat Chewing in Butajira, Ethiopia. Acta Psychiatrica Scandinavica, 100, 84-91. http://dx.doi.org/10.1111/j.1600-0447.1999.tb10699.x

Al-Mugahed, L. (2008). Khat Chewing in Yemen: Turning over a New Leaf. Bulletin of the World Health Organization, 86, 741-742. http://dx.doi.org/10.2471/BLT.08.011008

Alsanosy, R. M., Mahfouz, M. S., \& Gaffar, A. M. (2013). Khat Chewing among Students of Higher Education in Jazan Region, Saudi Arabia: Prevalence, Pattern, and Related Factors. BioMed Research International, 2013, 7 p.

Alsanosy, R. M., Mahfouz, M. S., \& Gaffar, A. M. (2013). Khat Chewing Habit among School Students of Jazan Region, Saudi Arabia. PLoS ONE, 8, e65504. 
Andualem Derese and Assefa Seme (2014). Substance Use and Risky Sexual Behaviors among Haramaya University Students.

Ataye District Health Office (2014). District Evidence Plan. Ataye: ADHO.

Awoke, S. E., Sintayoh, M., \& Berehe, K. K. (2011). Determine the Prevalence and Related Consequence of Khat Chewing among Students in College of Health Sciences, Mekelle University, Mekelle City 2011. International Journal of Therapeutic Applications, 11, 9-18.

Bitew, T., \& Tefera, S. (2014). A Review of Prevalence and Impacts of Khat in Ethiopia. http://khatresearch.org/JIMIS/Booklet.pdf

Damena, T., Mossie, A., \& Tesfaye, M. (2011). Khat Chewing and Mental Distress: A Community Based Study, in Jimma City, Southwestern Ethiopia. Ethiopian Journal of Health Sciences, 21, 37-45.

Deressa, W., \& Azazh, A. (2011). Substances Use and Its Predictors among Undergraduate Medical Students of Addis Ababa University in Ethiopia. BMC Public Health, 11, 660. http://dx.doi.org/10.1186/1471-2458-11-660

Ethiopian Public Health Association (2012). Alcohol, Tobacco and Substance Abuse. Annual Conference of Ethiopian Public Health Association, Addis Abeba, Oct 2011, 31.

Gebreslassie, M., Feleke, A., \& Melese, T. (2013). Psychoactive Substances Use and Associated Factors among Axum University Students, Axum Town, North Ethiopia. BMC Public Health, 13, 693.

Getahun, W., Gedif, T., \& Tesfaye, F. (2010). Regular Khat (Catha edulis) Chewing Is Associated with Elevated Diastolic Blood Pressure among Adults in Butajira, Ethiopia: A Comparative Study. BMC Public Health, 10, 390.

Hussein, A. M. (2009). Health and Socio-Ecomonic Hazards Associated with Khat Consumption. Journal of Family and Community Medicine, 25, 3-11.

Kebede, D., Alem, A., Mitike, G., Enquselassie, F., Berhane, F., Abebe, Y. et al. (2005). Khat and Alcohol Use and Risky Sex Behaviour among In-School and Out-of-School Youth in Ethiopia. BMC Public Health, 5, 109. http://dx.doi.org/10.1186/1471-2458-5-109

Kebede, Y. (2002). Cigarette Smoking and Khat Chewing among College Students in North West Ethiopia. Ethiopian Journal of Health Development, 16, 9-17. http://ejhd.uib.no/ejhdv16-n1/v16no16-page9.PDF

Kebede, Y., Abula, T., Ayele, B., Feleke, A., Degu, G., Kifle, A. et al. (2013). Substances Abuse for the Ethiopian Health Center Team. Ethiop Public Health Train Initiative 2005, 81.

Kennedy, J. G., Teague, J., Rikaw, W. et al. (1983). A Medical Evaluation of the Use of Qat in North Yemen. Social Science and Medicine, 17, 783-793.

Lemessa, D. (2001). Khat (Catha edulis): Botany, Distribution, Cultivation, Usage and Economics in Ethiopia. UN-Emergencies Unit for Ethiopia Addis Ababa.

Malaju, M. T., \& Asale, G. A. (2014). Factors Associated with Khat Use and Age at First Initiation among Youths in Southern Ethiopia. http://khatresearch.org/JIMIS/Booklet

Mulugeta, Y. (2013). Khat Chewing and Its Associated Factor among College Students in Bahir Dar Town, Ethiopia. Science Journal of Public Health, 1, 209-214. http://dx.doi.org/10.11648/j.sjph.20130105.14

Ndetei, D. M., Khasakhala, L. I., Mutiso, V., Ongecha-Owuor, F. A., \& Kokonya, D. A. (2010). Drug Use in a Rural Secondary School in Kenya. Journal of Substance Abuse, 31, 170-173. http://dx.doi.org/10.1080/08897077.2010.495313

Negussie, B., Damena, M., \& Egata, G. (2014). Substance Use, Prevalence and Determinant Factors among High School Students in Dire Dawa Administrative Council, Eastern Ethiopia.

Odenwald, M., Hinkel, H., Schauer, E., Neuner, F., Schauer, M., Elbert, T. R., \& Rockstroh, B. (2007). The Consumption of Khat and Other Drugs in Somali Combatants: A Cross-Sectional Study. PLoS Medicine, 4, e341. http://dx.doi.org/10.1371/journal.pmed.0040341

Oshodi, O., Aina, O., \& Onajole, A. (2010). Substances Use among Secondary School Students in an Urban Setting in Nigeria: Prevalence and Associated Factors. African Journal of Psychiatry, 13, 52-57.

Otieno, A. O., \& Ofulla, A. V. O. (2009). Drug Abuse in Kisumu Town Western Kenya. African Journal of Food, Agriculture, Nutrition and Development, 9, 846-858. http://dx.doi.org/10.4314/ajfand.v9i3.43010

Reda, A. A., Moges, A., Biadgilign, S., \& Wondmagegn, B. Y. (2012). Prevalence and Determinants of Khat (Catha edulis) Chewing among High School Students in Eastern Ethiopia: A Cross-Sectional Study. PLoS ONE, 7, e33946. http://dx.doi.org/10.1371/journal.pone.0033946 


\section{Abbreviation and Acronyms}

$\begin{array}{ll}\text { ADHO } & \text { Ataye District Health office; } \\ \text { BBB } & \text { Brain Blood Barrier; } \\ \text { BSc } & \text { Bachelor of Science; } \\ \text { CI } & \text { Confidence Interval; } \\ \text { COR } & \text { Crude Odd Ratio; } \\ \text { EPHA } & \text { Ethiopian Public Health association; } \\ \text { GLM } & \text { Generalized Linear Model; } \\ \text { OR } & \text { Odd Ratio; } \\ \text { PSU } & \text { Primary Sampling Unit; } \\ \text { SD } & \text { Standard Deviation; } \\ \text { SPSS } & \text { Statistical Package for Social Sciences; } \\ \text { WHO } & \text { World Health Organization. }\end{array}$


Scientific Research Publishing (SCIRP) is one of the largest Open Access journal publishers. It is currently publishing more than 200 open access, online, peer-reviewed journals covering a wide range of academic disciplines. SCIRP serves the worldwide academic communities and contributes to the progress and application of science with its publication.

Other selected journals from SCIRP are listed as below. Submit your manuscript to us via either submit@scirp.org or Online Submission Portal.
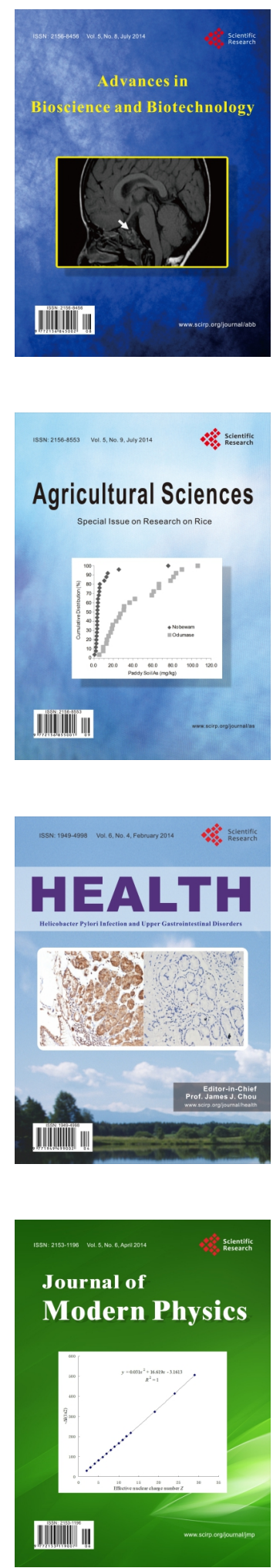
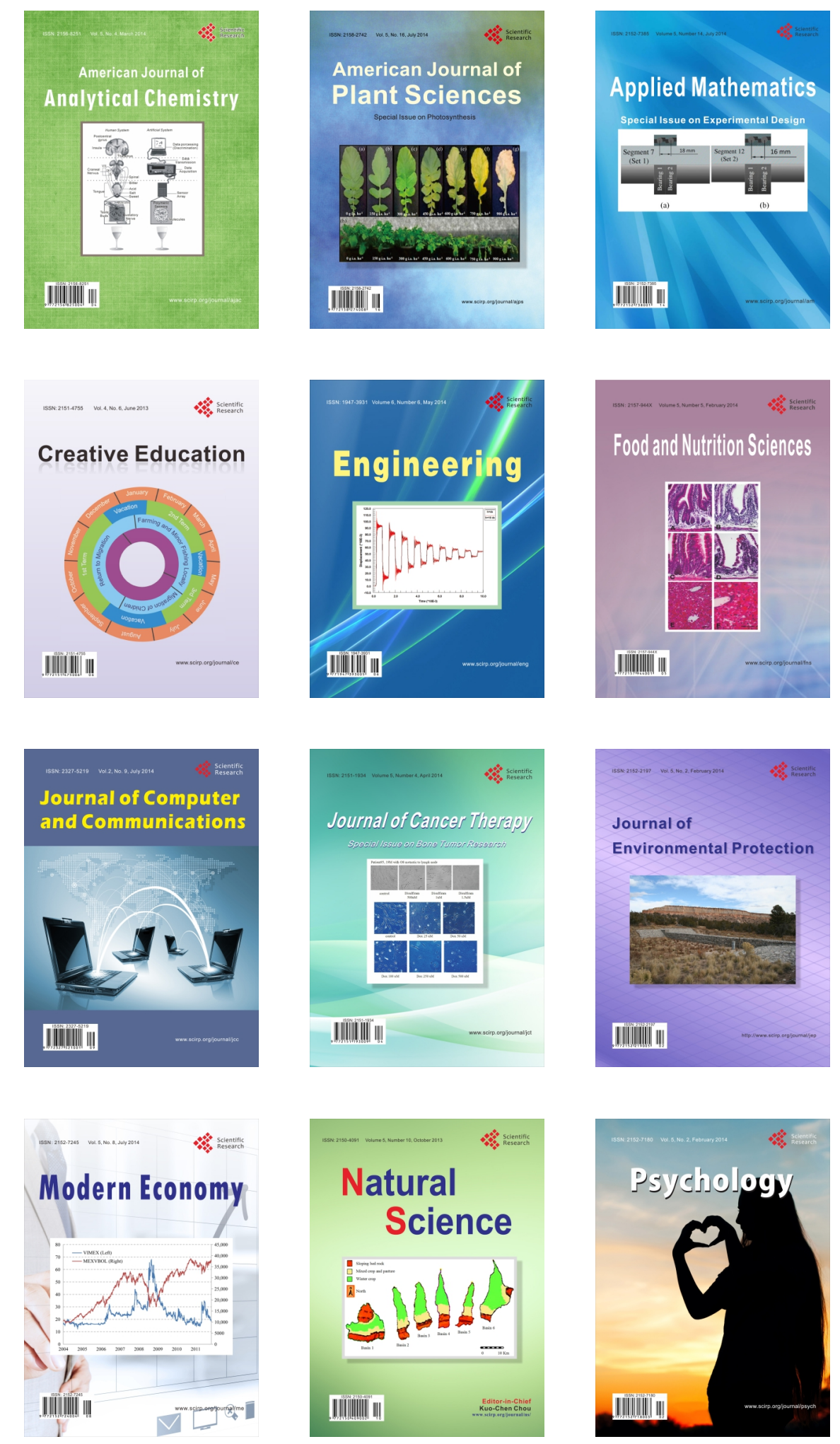